\title{
Siemenperunan vientimahdollisuudet
}

\author{
Leo Mustonen \\ Maa- ja elintarviketalouden tutkimuskeskus \\ Kasvintuotannon tutkimus \\ 31600 Jokioinen \\ leo.mustonen@mtt.fi
}

\section{Johdanto}

Siemenperunan tuotanto on perunanviljelyn kansainvälisesti kilpailukykyisin sektori. Siemenperunaa on viety kahtena viime vuotena noin 1000 tn. Siementä on viety useaan eri maahan ja kiinnostus vientiin on kasvamassa. Vienti laajassa mitassa edellyttää kuitenkin perunan fysiologisten ominaisuuksien hallintaa vientimaiden olosuhteissa. Siemenperunan fysiologinen ikä aiheuttaa epävarmuutta ja ongelmia, kun perunaa viedään Välimeren alueelle tai kauemmaksi, missä istutukset alkavat aikaisin keväällä. Meillä tuotettu siemenperuna ei ole tähän aikaan riittävästi virittynyt eikä kypsä istutettavaksi. Peruna on fysiologiselta iältään liian nuorta eikä se kasva normaalisti. Vientiedellytysten parantamiseksi meillä tuotetun perunan fysiologista kehitystä on joudutettava. Periaatteessa meillä tuotetun, nuoren siemenperunan sadontuottokyky on hyvä pitkän kasvukauden oloissa. Nuori elinvoimainen, siemen kestää kuivuutta ja epäedullisia kasvuoloja vanhaa siementä paremmin.

Kun perunaa viedään Suomen lähialueille tai Länsi-Eurooppaan, missä perunan istutusaika ja kasvuolot ovat meitä vastaavat, siemenperunan ominaisuudet eivät aiheuta ongelmia

Fysiologinen ikä voi aiheuttaa ongelmia myös silloin, kun peruna käytetään siemeneksi myöhään kesällä tai alkusyksystä. Silloin siemenperuna voi olla fysiologiselta iältään liian vanhaa ja sen sadontuottokyky on heikentynyt ( Schulmann 1998, Wiltshire \& Cobb 1996 ).

Tässä tutkimuksessa selvitettiin perunan itämislevon ja fysiologisen iän säätelyä. Tavoitteena oli muuttaa perunan fysiologista kehitystä siten, että perunaa voitaisiin käyttää siemeneksi jo aikaisin talven ja kevään aikana. Toisaalta selvitettiin myös mahdollisuutta säilyttää peruna siemeneksi kelpaavana mahdollisimman pitkään, jopa alkusyksyyn asti.

\section{Aineisto ja menetelmät}

Aineistossa ovat mukana vuonna 1997-98 MTT:n Kasvintuotannon tutkimuslaitoksessa Jokioisissa ja Pohjois-Pohjanmaan tutkimusasemalla tehdyt kenttäkokeet. Kokeet varastoitiin MTT:n koevarastossa Jokioisissa. Mukana olivat aikainen ( 20.8. ) ja normaali ( 30.8. ) korjuuajankohta sekä varsistonhävitys 10 vrk ennen nostoa. Kylmäkäsittely $\left(+2{ }^{\circ} \mathrm{C}, 21\right.$ vrk $)$ ja lämpökäsittely $\left(+28{ }^{0} \mathrm{C}, 21\right.$ vrk ) tehtiin ennen varastointia. Varastointilämpötila oli $+4^{0} \mathrm{C}$ ja kosteus $95 \% \mathrm{RH}$. Koelajikkeet olivat Bintje, Asterix, Nicola ja Satu. Kokeesta otettiin 30 vrk välein näytteet, joista määritettiin itämislevon pituus ( vrk ) ja itujen lukumäärä (kpl). Samanaikaisesti kasvihuoneessa määritettiin perunan alkukehitys ja varsien lukumäärä. Alkukehitys määritettiin varsiston tuore- ja kuivaainesadon perusteella 30 vrk kuluttua istutuksesta.

\section{Tulokset}

\section{Itämislepo}

Itämislepo on perunan kehitysjakso, jolloin peruna ei idä vaikka olosuhteet olisivat itämiselle suotuisat. Itämislevon pituus lasketaan mukulanmuodostuksen tai noston ajankohdasta perunan itujen 
( >2 mm ) kasvun alkuun. Kylmä- ja lämpökäsittelyt lyhensivät selvästi kaikkien lajikkeiden itämislevon pituutta. Lajikkeista Bintjen itämislepo oli lyhin ja Sadun jonkin verran muita lajikkeita pidempi. Kylmäkäsittely nopeutti Bintjen itämisen alkamista käsittelemättömään verrattuna 27 vrk ja Sadun 16 vrk. Lämpökäsittely ei vaikuttanut yhtä voimakkaasti mutta nopeutti itämisen alkamista lajikkeesta riippuen 9-15 vrk (Taulukko 1). Nostoajankohdan ja koepaikan vaikutus itämislepoon oli selvästi pienempi kuin kylmä- ja lämpökäsittelyn vaikutus. Kylmäkäsittelyn itämislevon pituuteen on samankaltainen kuin Hollannissa tehdyissä tutkimuksissa, joskin lajikkeiden reagoinnissa esiintyy huomattavaa vaihtelua ( Van Ittersum \& Scholte 1992 ).

Taulukko 1. Lämpö- ja kylmäkäsittelyn vaikutus perunan itämislevon pituuteen. Itämislevon pituus (vrk) mukulanmuodostuksen alusta.

\begin{tabular}{lllll}
\hline & \multicolumn{3}{c}{ Itämislepo, vrk } \\
Koejäsen & Bintje & $\begin{array}{l}\text { Asteri } \\
\mathrm{x}\end{array}$ & Nicola & Satu \\
\hline Kontrolli & 150 & 153 & 154 & 156 \\
Lämpökäsittely & 142 & 144 & 139 & 144 \\
Kylmäkäsittely & 123 & 129 & 127 & 140 \\
\hline
\end{tabular}

\section{Itujen lukumäärä}

Kun peruna itämislevon päätyttyä itää, tavallisesti vain kärkisilmu tai sen sivusilmut virittyvät ja ituja muodostuu vähän. Samalla kärkisilmun hormonaalinen vaikutus estää myös alempien silmujen virittymisen. Ilmiötä kutsutaan kärkisilmun vallitsevuudeksi. Kun perunan fysiologinen kehitys varastoinnin aikana etenee, ituja muodostuu enemmän ja enemmän, kunnes lajikkeelle ominainen itujen lukumäärä saavutetaan. Jos kärkisilmun idut poistetaan, itujen lukumäärä kasvaa normaaliksi, kärkisilmun hormonaalisen vaikutuksen lakatessa. Kylmä- ja lämpökäsittelyt lisäsivät itujen lukumäärää määritysajankohdasta ja lajikkeesta riippuen. Lämpökäsittely joudutti perunan fysiologista kehitystä ja lisäsi kaikkien lajikkeiden itujen lukumäärää enemmän kuin kylmäkäsittely. Kun lämpökäsittelyä verrattiin koejäseneen, jonka kärkisilmun idut poistettiin, itujen lukumäärä oli lajikkeelle tyypillisellä tasolla helmikuun aikana. Käsittelemättömässä koejäsenessä itujen lukumäärä kasvaa lajikkeelle tyypilliselle tasolle huhtikuun aikana.

\section{Alkukehitys}

Perunan kasvuvoimaa ja soveltuvuutta siemenperunaksi selvitettiin kasvihuonekokeessa. Alkukehitys määritettiin varsiston tuoresadon perusteella 30 vrk kuluttua istutuksesta. Lämpö- ja kylmäkäsittely lisäsivät voimakkaasti perunan kasvua joulu-helmikuun välisenä aikana. Lämpökäsittely lisäsi eniten Satu-lajikkeen kasvua, joka virittyi muita lajikkeita hitaammin. Myös muiden lajikkeiden kasvu oli tammi-helmikuun aikana käsittelemättömään verrattuna lähes kaksinkertainen (Kuva 1). Lämpö- ja kylmäkäsittelyt parantavat perunan kasvuvoimaa ja lisäävät käyttömahdollisuutta siemeneksi, kun peruna istutetaan tavallista aikaisemmin. Tulokset osoittivat laajankin siemenperunan viennin olevan mahdollista. Tutkimusta tarvitaan kuitenkin lisää ennen kuin käytännön ratkaisut voidaan vakiinnuttaa. 


\section{Siemenen fysiologinen vanheneminen}

Kun perunaa käytetään siemeneksi myöhään kesällä tai alkusyksystä, peruna voi olla fysiologiselta iältään liian vanha. Voimakkaimmillaan tämä ilmenee, kun peruna muodostaa maavarsia ja mukuloita, mutta ei kykene kasvattamaan lainkaan varsistoa. Kun siemen on liian vanha, varsia muodostuu yleensä paljon, mutta varsisto on matala ja tuleentuu aikaisin. Vanhan siemenperunan sadontuottokyky on tavallisesti heikko. Siemenperunakeskuksen kanta-aineistolla Jokioisissa syksyllä 1999 tehdyissä kokeissa todettiin, että meillä tuotettu nuori siemen säilyy käyttökelpoisena pitkälle alkusyksyyn. Fysiologista vanhenemista nopeutettiin myös poistamalla idut, mutta tämäkään ei tuonut esille liian vanhalle siemenelle tyypillisiä ilmiöitä. Käytännön ongelmana on voimakas itujen kasvu pitkään kestävän varastoinnin aikana.

Bintje

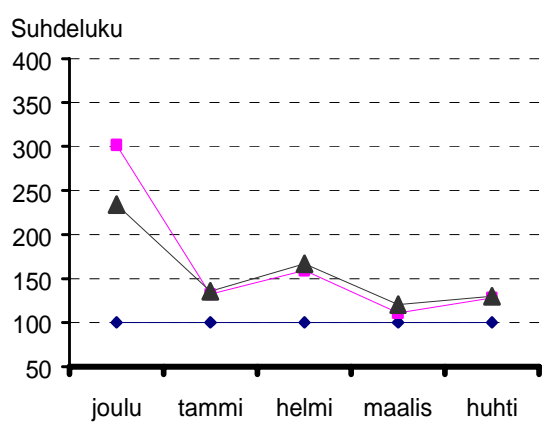

Nicola

Suhdeluku

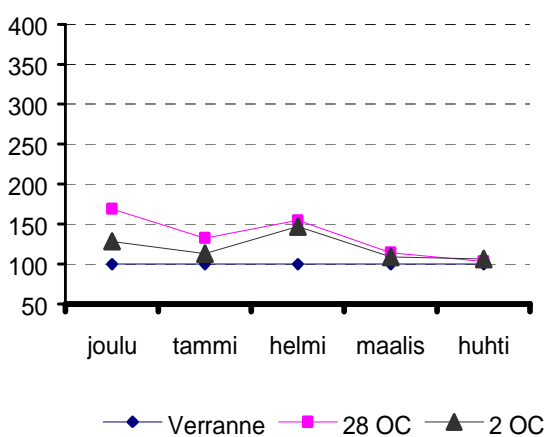

Asterix

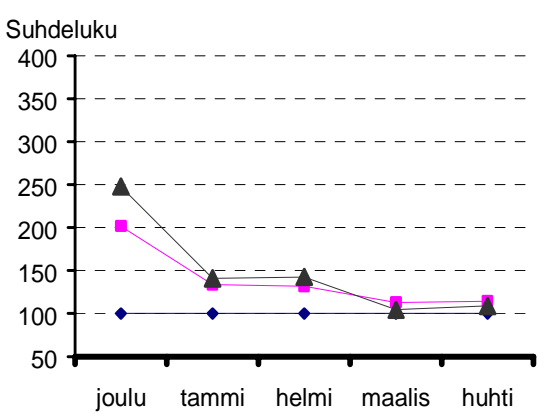

Satu

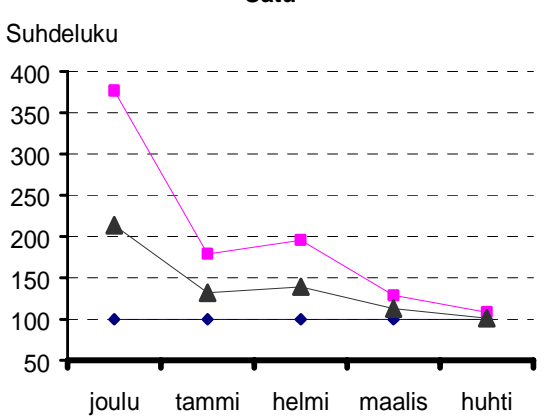

Kuva 1. Lämpökäsittelyn $\left(+28{ }^{\circ} \mathrm{C}, 21\right.$ vrk $)$ ja kylmäkäsittelyn $\left(+2{ }^{\circ} \mathrm{C}, 21\right.$ vrk $)$ vaikutus perunan alkukehitykseen kasvihuonekokeessa eri määritysajankohtina. Perunan alkukehitys on mitattu varsiston tuorepainon perusteella, tulokset esitetään suhdelukuina verrannekäsittelyyn. 


\section{Kirjallisuus:}

Schulmann, P. 1998. Der Planzgutwert von Kartoffeln aus der Sicht des physiogishen Alters. Der Kartoffelbau 49: 134-136.

Ittersum, M. K. Van \& Scholte, K. 1992. Shortening of dormancy of seed potatoes by storage temperature regimes. Potato Research 35: 389-401.

Wiltshire, J. J. J. \& Cobb, A. H. 1996. A rewiew of the physiology of potato tuber dormancy. Annals of Applied Biology 129: 553-569. 